2021, Volume 16, ATEE 2020 - Winter Conference. Teacher Education for Promoting WellBeing in School. Suceava, 2020, pages: 530-551।

https://doi.org/10.18662/lumproc/atee2020/37

\section{Children's \\ Wellbeing Starts at Home. Redefining Parenting According to the Digitalized Society}

Mihaela VOINEA ${ }^{1}$

\section{Andreea ŞIT,OIU 2}

${ }^{1}$ Transilvania University, Faculty of Psychology and Educational Sciences, Brasov, Romania mihaela.voinea@unitbv.ro

2 Assistant professor, Faculty of Psychology and Educational Sciences, Transilvania University andreea.sitoiu@unitbv.ro
Abstract: The changes in digitalized society are reflected in the family and school environment.

Nowadays children are characterized as "Homo zappiens" (Veen \& V rakking, 2011) or "digi" generation (Gold, 2016) because they are growing up using modern technology (mobile phone, computer, iPod etc.) since early childhood. The use of new communication technologies by children induced major changes in play, learning and parenting. They learn and play in a global and digital culture. This could lead to buge discrepancies between generations, especially between parents and cbildren, children and educators. This is because bomo rappiens are digital, whereas parents are analogous sometimes. If we add to these characteristics of society the values that dominate postmodernism (bedonism, individualism etc.) we will have a clearer picture of the challenges of education today and especially, in parenting. We need to redefine the children-parents-educators relationship through a new set of criteria. Wellbeing is an important aspect of the family environment which determinates school integration and success.

This article focuses on research in parents' perception regarding the parenting in digitalized society and children's wellbeing.

The research was embedded in a constructivist-interpretivist paradigm, which employed both quantitative and qualitative methods for data collection. This study included a number of 100 participants, cbildren and their parents.

Conclusion: The parents need to develop a new mind, set on children's wellbeing and retbinking the parenting in digitalized society. A training program for parents must be a solution for develop cbildren's well-being at home as a condition for school.

Keywords: wellbeing, parenting, digitalized society, parent-child partnership, emotions.

How to cite: Voinea, M. \& Şițoiu, A. (2021). Children's Wellbeing Starts at Home. Redefining Parenting According to the Digitalized Society. In O. Clipa (vol. ed.), Lumen Proceedings: Vol. 16. ATEE 2020 - Winter Conference. Teacher Education for Promoting Well-Being in School. Suceava, 2020 (pp. 530-551). Iasi, Romania: LUMEN Publishing House. https://doi.org/10.18662/lumproc/atee2020/37 


\section{Introduction:}

This article focuses on the changes in parenting in digitalized society. The aim of the research is to identify the perception of parents who need to take good care of a child in a digital society. The well-being of a child is essential for creating a harmonious, emotionally healthy and cognitively competent adults. At this point, they can be seen well, in the first years of life, but also long after that, it largely depends on the parenting style adopted by the parent of the child, but also the ability of the parent to adapt to the requirements of the digital age.

With the advancement of digital resources, parents are also presented with new responsibilities, namely to teach children to resist distraction, following a technology to care for or use (Palladino, 2015).

\section{The research gap}

Parenting in digitalized society- a new paradigm of parenting education?

A review of parenting research in last two decades - A. Kohn (2015; 2017); T. Gordon $(2003 ; 2014)$, underlines a paradigm shift from children education to parents' education.

This change is a result of major individual and social changes in all aspects of life.

The first major change can be easily observed at social level. The digitalized society with all its vulnerabilities and strengths brings with it a new model of social competences, a new social ethic. For example, social values as responsibility, innovation, self-development, social and emotional competences and critical thinking are nowadays the main tools of social adaptation. These social and moral values/competences specific for the $21 \mathrm{st}$ century are a result of digitalization because is a known fact, since 1982, that high technological developmental determines high human reactions. The social changes are synthetized in table 1. 
Table 1. Changes in digitalized society vs competences for future

\begin{tabular}{|c|c|}
\hline $\begin{array}{l}\text { Changes in digitalized } \\
\text { society }\end{array}$ & Competences for future \\
\hline Digitalization & Digital competences/ a new culture \\
\hline Social media/ communications & Critical thinking \\
\hline Change in labour market & Entrepreneurial competences/ innovation \\
\hline Family structure changes & Unconditional Parenting (Kohn) \\
\hline Education & $\begin{array}{c}\text { Digital education / future competences } \\
\text { /transformative competence } \\
\text { Digital lifelong learning }\end{array}$ \\
\hline $\begin{array}{l}\text { Changing the parenting } \\
\text { paradigm }\end{array}$ & $\begin{array}{l}\text { Parental competence, which includes: } \\
\text { knowledge of the child's age, child } \\
\text { discipline, parent-child time management, } \\
\text { emotional support and crisis management. } \\
\text { All these components make up the } \\
\text { factorial model of parental competence, } \\
\text { developed following studies conducted by } \\
\text { Simona Glăveanu. }\end{array}$ \\
\hline
\end{tabular}

The second change is visible in education. The new theories of emotional intelligence, the role of emotions in learning (Cozolino, 2017), study regarding to brain development show that for it to obtain good results in learning, students must be involved in an authentic learning process, doing significant things for their education and share the learning experiences with their colleagues.

Nowadays children are characterized as "Homo zappiens" (Veen \& Vrakking, 2011) or "digi" generation (Gold, 2016) because they are growing up using modern technology (mobile phone, computer, iPod etc.) since early childhood. 
The use of new communication technologies by children induced major changes in play, learning and parenting. They learn and play in a global and digital culture. This could lead to huge discrepancies between generations, especially between parents and children, children and educators. This is because homo zappiens are digital, whereas parents are analogous. If we add to these characteristics of society the values that dominates postmodernism (hedonism, individualism etc.) we will have a clearer picture of the challenges of education today and especially, in parenting.

All these social changes affect directly the family lifestyle and parentchildren relationship. A proof is the new parent's trend to developing parental competences to raise adapted children. But the problem is that the parents still have an immigrant digital" attitude and children are digital native. Solutions are to educate parents according to new trends of society and children education. This is a priority in education because the fundamentals of education starts in family and new structure of family (single-parent families, families that include parents who carry out a professional activity abroad, a family whose financial income is reduced due to unemployment) redefine the role and responsibilities of parents.

The family is and will be an environment which prepares children for social life. The family offers the emotional support for all essential human experiences and development.

\section{The well-being of the child of the digital age}

The well-being of the child, in the 21st century, can be ensured and can be mediated by the parents availability for learning.

According to the new paradigm of parenting, parents need to acquire skills in using technology, as the children of today's society, also acquire well-being through digital resources. These skills can also be acquired with the help of their own children, modern parenting encouraging the parentchild partnership and from the perspective of the help they can offer each other. According to a constructionist theory, when parents and children engage in an activity together, they will learn better and easier the notions useful for performing tasks or for operating with different applications or digital devices, in this case (Bers et al., 2004). 
Constructionism has its origins in Piaget's constructivist theory. While Piaget's theory explains how knowledge is constructed in the human brain, Papert's constructionist theory offers explanations of how elements in the environment are points of support for knowledge in the human brain. According to Papert's theory, computers are particularly useful tools with which the human being can create a multitude of creative things (Bers et al., 2004).

\section{Well-being in society/education and family}

The society of the 21 st century, which is constantly changing and offering challenges everywhere, is characterized by diversity, rapid social changes, individualism and consumerism. Last but not least, today's society is also characterized by the widespread use of technology in most areas of professional activity, but also in personal life.

The diversity manifested at the level of society, offers the individual the possibility to choose how he wants to live his life and implicitly to the parent, to adopt the parental style considered suitable for the upbringing and education of his child. In postmodern society, there is a growing interest in the permissiveness of the parent to the child, to the detriment of excessive authority.

Social changes take place at different levels: in a working group, through the processes of cooperation and collaboration, in an economic organization, through the process of transformation of the content of the professional activity, respectively in a professional community, through the dynamics registered at the process of reporting individuals to the ethics of the field.

Information and computer technology, computerization, respectively automation, have determined decisive transformations in the field of economy, infrastructure, but also in the field of science, all these influencing social changes. Therefore, the following were identified: a decrease in trust in the professional authority as the possibility of information increased; an increase in individualization concomitant with the decrease in cultural and scientific autonomy, as a result of the explosion of information and access to information at all times (Voicu et al., 2016). 
Another feature of today's society is the presence of individualism. Its components are autonomy, self-responsibility and individual uniqueness. In the field of psychology, the first to operationalize the concept of individualism was Hofstede (1980; 1991), who used this term to describe the relationships that are established between individuals and the groups to which they belong. According to his understanding, individualism refers to a society in which the connections between individuals are based on their freedom of choice and it is expected that each individual will be concerned only with himself and his close family (Realo et al., 2002).

Along with individualism, the society of the 21 st century, is also notable for the presence of consumerism which involves the exploitation of material and human resources, without taking into account the needs of people, their possibilities, interspersing professional life with family.

As a result of diversity, social change, individualism and consumerism, the family of postmodern society is characterized by diverse structures, family crises, such as unemployment, divorce, violence, respectively by establishing a fragile boundary between professional and personal life.

One of the concepts increasingly used today is well-being. It can be seen as a result of human need to cope with the digitalization.

Concerns for the promotion of well-being at the social level are a result of new conceptions regarding the health and well-being of the individual integrated in society. In accordance with this statement, we draw attention to the fact that the judgment of an individual's well-being is interdependently related to the society to which the individual belongs.

The analysis of the definitions of the concept of well-being demonstrates the fact that there is a difficulty to measure this well-being, because besides the objective, quantifiable dimensions that it implies, there is also a subjective, psychological dimension difficult to surprise, respectively evaluate.

Despite the non-existence of unanimously recognized explanatory models regarding the good state, the idea that well-being is the foundation / engine of individual and social development is still accepted. 
It is no coincidence that the concern for the well-being of children and students in school, respectively, becomes a concern of education specialists. It is possible that an argument for this concern is the increasingly alert spread of the concept of emotional intelligence. This type of intelligence can help ensure and maintain the well-being of society, parents and implicitly their children.

Andy Hargreaves, specialist in education, underlines that we are in transition through a new era. In the past (in XX century), the cognitive results (from international evaluations) were the major educational objective. Now the well-being is the most important educational goal.

The Finnish school model is an argument in this regard. One of the principles of this school is to adapt the contents to the child's needs, respectively to the areas that ensure their well-being. We can say that this model of the Finnish school becomes a precursor to changing the attitude of society, respectively the family, in terms of ensuring the well-being of the child.

\section{Research questions/Aims of the research}

The purpose of this research is to identify parents' perceptions of children's well-being, as well as the willingness of adults to adapt to a technological society.

The formulation of these goals corresponds to the new paradigm of parenting, according to which the development of parental competence is encouraged, the adaptation of the parent to the needs of his child, respectively unconditional love.

This study is based on the formulation of the following research questions:

1. What are the strategies of the parents of today's society, in terms of ensuring the well-being of their child?

2. How much availability the parents of the 21st century demonstrate, for studying parenting strategies in accordance with the characteristics of the technological society.

3. Do parents appreciate that technology is useful for their child's development? 
4. Are parents interested in creating a parent-child partnership to ensure the child's well-being?

5. Do the parents of the technological age manage to manage the time that the child spends using technology?

6. Do today's parents manage to adapt to the changes brought about by today's society?

7. Is the child's well-being considered by the parent a reward for his child?

8. Did the technological society represent the determining factor of the emotional rupture between the parent and his child?

\subsection{Research objectives}

1. Identify the strategies that the parents of today's society use to ensure the well-being of the child.

2. Analyzing the level of availability of parents to study parenting strategies in accordance with the characteristics of the technological society.

3. Establishing the trend among parents regarding the usefulness of technology for their child's development.

4. Identifying the tendency of parents to create a parent-child partnership in order to ensure the well-being of the child.

5. Analyzing the way in which the parents of the 21 st century manage the time that the child spends using technology.

6. Establishing the level of adaptation of parents to the technological society.

7. Identifying the parents' perception of ensuring the child's wellbeing in the form of a reward.

8. Analyzing how the technological society caused an emotional rupture between the parent and his child.

\subsection{Research hypotheses}

1. Parents of the 21st century, show involvement in ensuring the well-being of their child. 
2. The parents of the current society, show availability for studying an informative material about the parenting strategies corresponding to the digitized society.

3. The usefulness of technology for children's development is also recognized in the case of parents participating in the study.

4. Today's parents believe that the parent-child partnership can help ensure the child's well-being.

5. Managing the time that the child spends using technological resources is a difficulty for the parents of today's society.

6. The technological society determines the current parent to adapt to it in order to ensure the well-being of the child.

7. Ensuring the well-being of the child, by the parents, in the form of a reward is associated with the aging of the parents.

8. The emotional rupture between parent and child caused by the technological society is not felt by today's parents at a high level.

\section{Research methods}

\subsection{Participants}

The present study was conducted in a mixt methods structure, embedded in a constructivist-interpretivist research paradigm (Patton, 2002).

To start this research, two research methods were used: a method specific to the qualitative paradigm, namely the interview, respectively a method specific to the quantitative paradigm, namely, indirect inquiry.

The interview was attended by 19 participants: 18 female (94.7\%) and 1 male respondent $(5.3 \%)$

From the point of view of age, this interview was attended by 3 respondents whose age falls in the range of $20-30$ years (15.8\%), 9 respondents in the age range 30-40 years $(47,4 \%), 6$ respondents in the age range $40-50$ years $(31.6 \%)$ and 1 respondent whose age is over 50 years $(5.3 \%)$.

From the point of view of the age of the children participating in the study, they are part of the following age ranges: 0-3 years - 4 children; 3-6 
years - 3 children; 6-9 years - 4 children; 9-12 years - 7 children and 5 children, whose age exceeds 12 years.

According to the age of the children for whom the parents answered the questions asked during the interview, they are part of the following age ranges: 0-3 years $(7.1 \%)$ - 1 child; 3-6 years (14.3\%) - 2 children; 6-9 years $(14.3 \%)-2$ children; 9-12 years (28.6\%) - 4 children and 5 children, representing $35.7 \%$ whose age exceeds 12 years.

The questionnaire was attended by 100 respondents, 90 (90\%) female and $10(10 \%)$ male.

The distribution of respondents according to the age group they belong to is as follows: $6(6 \%)$ respondents - 25-30 years; 19 (19\%) respondents - 30-35 years old; 23 (23\%) respondents - 35-40 years old; 32 (32\%) respondents - 40-45 years old; $12(12 \%)$ respondents - 45-50 years old and $8(8 \%)$ respondents - over 50 years old. Of the 100 respondents, 60 $(60 \%)$ have children in primary school, $22(22 \%)$ have children in middle school, and $18(18 \%)$ have children in high school.

\subsection{Materials and instruments}

To test the study hypotheses, the following tools were used: the interview guide corresponding to the interview method and the questionnaire corresponding to the indirect survey method.

Interview guide for identifying parents' perceptions of well-being

The interview guide is structured in two parts. The first part includes the identification data of the study participants: gender, age range of the respondent child / children and the age range of the child for which the study participant answered the questions asked.

The second part of the interview guide includes the following questions / items:

1. What color do you associate your well-being with?

2. What does the well-being of your child mean to you?

3. Concrete description of a situation / activity, in which you are sure that your child is experiencing well-being.

4. What color do you associate your child's well-being with?

5. What do you do concretely to ensure the well-being of your child? 
The questionnaire aimed at adapting the parent to the technological society

The indirect survey method envisages the application of a questionnaire consisting of 26 questions. In the construction of the questions will be used the nominal scale with the possibility of single choice, with the possibility of multiple choice, the binary scale, the semantic scale, respectively the numerical scale.

Of the 26 questions in the questionnaire, the following were used to test the hypotheses, but also to formulate the study's conclusions:

I agree with the statement that "Technology is essential for the development of my child": 1 - total agreement, 2- agreement, 3 - neither agreement nor disagreement, 4 - disagreement, 5 - total disagreement;

I agree with the phrase "My child could teach me how to use technology": 1 - Yes, 2 - No;

I happened to feel that I no longer have authority over my child since technology took over his free time: 1 - Less than 5 times, 2 - 5-10 times, 3 - 10-15 times; 4 - Over 15 times;

Although I am aware that there are times when my child exaggerates with the use of technology, I do not know how to stop this: 1 - To a very small extent, 2 - To a small extent, 3 - To a moderate extent, 4 - To a large extent, 5 - To a very large extent;

There are times when I would like to spend more time with my child, but video games or smart applications take over: 1 - Less often than once a month, 2 - Once a month, 3 - Two times a month, 4 - 3-4 times a month, 5 - More than 4 times a month;

I consider that my life as a parent would be easier if I learned to see the benefits of technology: 1 - To a very small extent, 2 - To a small extent, 3 - To a moderate extent, 4 - To a large extent, 5 - To a very large extent measure;

I think that the best reward for my child is the permission to use the technology: 1 - Total agreement, 2 - Agreement, 3 - Neither agree nor disagree, 4 - Disagree, 5 - Total disagreement; 
The advancement of technology has created an emotional rupture between me and my child: 1 - To a very small extent, 2 - To a small extent, 3 - To a moderate extent, 4 - To a large extent, 5 - To a very large extent.

\subsection{Procedure}

The interview guide was applied in May, over the phone, and the answers were noted and then interpreted to test the hypotheses.

The questionnaire was applied online, and the answers were entered in the SPSS database, and based on them, frequencies and correlations were generated for testing the hypotheses.

\section{Results}

To test the hypothesis that 21 st century parents demonstrate involvement in ensuring the well-being of their child, the responses of the interview participants were analyzed, finding the following:

1. The well-being of the child, from the perspective of the parent, is associated with: experiencing the feeling of happiness, experiencing the feeling of peace and inner peace, health, as well as self-satisfaction.

2. Parents participating in the study are sure that their child experiences well-being when play predominates in their activities (on the phone, outdoors, with other playmates or independent play), when the parent spends time with his child, respectively activities that involve movement or listening to music.

3. From the point of view of ensuring the well-being of the child by the parent, the respondents stated that they diversify the activities, pay attention to the child, respectively offer him the freedom of decision.

Starting from the conclusions summarized after analyzing the answers, the hypothesis according to which 21 st century parents, demonstrates involvement in ensuring the well-being of their child, is confirmed.

Table 2. Analysis of the answers of the interview participants

\begin{tabular}{c|c|c}
\hline $\begin{array}{c}\text { 2. What does the well- } \\
\text { being of the child mean } \\
\text { to you? }\end{array}$ & $\begin{array}{c}\text { 3. Describe concretely, a } \\
\text { situation or activity in } \\
\text { which you are sure that } \\
\text { your child is experiencing }\end{array}$ & $\begin{array}{c}5 . \text { What do you do } \\
\text { concretely to ensure the } \\
\text { well-being of your child? }\end{array}$ \\
\hline
\end{tabular}




\begin{tabular}{|c|c|c|}
\hline & well-being. & \\
\hline $\begin{array}{c}\text { To experience the feeling } \\
\text { of happiness }\end{array}$ & Activity involving play & Diversification of activities \\
\hline $\begin{array}{c}\text { To listen to him when he } \\
\text { wants to express his } \\
\text { thoughts, feelings }\end{array}$ & $\begin{array}{l}\text { Activity that involves playing } \\
\text { on the phone }\end{array}$ & $\begin{array}{l}\text { I give him the attention he } \\
\text { needs }\end{array}$ \\
\hline $\begin{array}{l}\text { To laugh, to be healthy, to } \\
\text { integrate in the groups he } \\
\text { belongs to }\end{array}$ & $\begin{array}{l}\text { Activity involving outdoor } \\
\text { play }\end{array}$ & I spend time with my child \\
\hline $\begin{array}{l}\text { To be satisfied with } \\
\text { everything he has, with } \\
\text { everything that happens to } \\
\text { him, to have a healthy diet }\end{array}$ & $\begin{array}{l}\text { Activity that involves playing } \\
\text { with other play partners }\end{array}$ & $\begin{array}{l}\text { I get involved in his } \\
\text { activities, I communicate } \\
\text { with my child and I explain } \\
\text { the situations that arise }\end{array}$ \\
\hline To smile & $\begin{array}{l}\text { The situation in which I } \\
\text { arrive home from work }\end{array}$ & $\begin{array}{l}\text { I give him everything he } \\
\text { needs }\end{array}$ \\
\hline To experience joy & $\begin{array}{l}\text { The situation in which we } \\
\text { spend quality time }\end{array}$ & $\begin{array}{c}\text { I spend as much time with } \\
\text { him as possible, primarily in } \\
\text { nature }\end{array}$ \\
\hline To feel inner peace & $\begin{array}{l}\text { The situation in which he } \\
\text { carries out an independent } \\
\text { activity, which involves } \\
\text { attention in order to succeed }\end{array}$ & $\begin{array}{l}\text { I intervene balanced in the } \\
\text { activities and moments when } \\
\text { he needs me }\end{array}$ \\
\hline $\begin{array}{l}\text { To feel that he is in the } \\
\text { first place in our family }\end{array}$ & $\begin{array}{l}\text { Activity involving movement } \\
\text { in has free }\end{array}$ & $\begin{array}{l}\text { I make sure he doesn't miss } \\
\text { anything, including materially }\end{array}$ \\
\hline To smile & $\begin{array}{l}\text { Activity that involves telling, } \\
\text { before going to bed, the } \\
\text { events that happened during } \\
\text { the day }\end{array}$ & $\begin{array}{c}\text { I make sure we communicate } \\
\text { as best we can }\end{array}$ \\
\hline $\begin{array}{l}\text { To smile, to sing, to be } \\
\text { happy }\end{array}$ & $\begin{array}{l}\text { Activity involving outdoor } \\
\text { play }\end{array}$ & $\begin{array}{l}\text { I give him the freedom to } \\
\text { play the way he wants }\end{array}$ \\
\hline $\begin{array}{l}\text { To be happy, to laugh, to } \\
\text { play }\end{array}$ & $\begin{array}{l}\text { Activity that involves playing } \\
\text { ball }\end{array}$ & $\begin{array}{l}\text { I spend as much time as } \\
\text { possible with my child }\end{array}$ \\
\hline $\begin{array}{l}\text { Be involved in various } \\
\text { activities }\end{array}$ & Activity involving sport & I spend time with him \\
\hline Be relaxed, carefree & $\begin{array}{l}\text { An activity that involves } \\
\text { spending time with friends }\end{array}$ & $\begin{array}{c}\text { It gives them the freedom to } \\
\text { choose how to spend their } \\
\text { free time }\end{array}$ \\
\hline Be calm & $\begin{array}{l}\text { Activity involving cycling } \\
\text { training }\end{array}$ & I support his election \\
\hline Be healthy and happy & $\begin{array}{l}\text { Activity that involves } \\
\text { preparing desserts }\end{array}$ & $\begin{array}{l}\text { I give him the opportunity to } \\
\text { experiment, I listen to him } \\
\text { when he expresses his point } \\
\text { of view, I respect his } \\
\text { opinions and privacy }\end{array}$ \\
\hline Be healthy and playful & Activity that involves cycling & $\begin{array}{c}\text { I'm with him as much as I } \\
\text { can }\end{array}$ \\
\hline To be healthy & $\begin{array}{l}\text { An activity that involves } \\
\text { experiencing feelings of }\end{array}$ & $\begin{array}{l}\text { I do everything in my power } \\
\text { for my child }\end{array}$ \\
\hline
\end{tabular}




\begin{tabular}{c|c|c}
\hline & peace and happiness & \\
\hline To be satisfied with himself & $\begin{array}{c}\text { An activity that involves } \\
\text { listening to music after a } \\
\text { tense experience }\end{array}$ & $\begin{array}{c}\text { I'm trying to give him an } \\
\text { understanding }\end{array}$ \\
\hline Be happy & $\begin{array}{c}\text { Activity that involves } \\
\text { following the rules he } \\
\text { imposes }\end{array}$ & $\begin{array}{c}\text { I give him arguments for any } \\
\text { decision, situation }\end{array}$ \\
\hline
\end{tabular}

The hypothesis according to which the parents of the current society, show availability for studying an informative material about the parenting strategies corresponding to the digitized society, was tested by calculating the frequency with which the respondents requested an informative material. This request could be made by noting the email address at the beginning of the questionnaire. Of the 100 respondents, 50 responded in the affirmative to this request, concluding that the parents participating in the research show interest in studying the topic of the study, but a larger sample is needed for this conclusion to be extrapolated to the entire parent population. According to this study, the hypothesis is confirmed, which can demonstrate that the concern of parents for parenting strategies appropriate to the digital society, helps to ensure the well-being of children in the family and later in society.

Table 3. Participants' interest in studying the research topic

\begin{tabular}{cccccc} 
& & & & Cumulative \\
Valid & Yes & 50 & 50.0 & 50.0 & 50.0 \\
& no & 50 & 50.0 & 50.0 & 100.0 \\
& Total & 100 & 100.0 & 100.0 & \\
\hline
\end{tabular}

In terms of the importance of technology for children's development, out of the 100 respondents, 28 fully agree with this statement, while a number of 50 agreed. After measuring this frequency of responses, we can notice an openness of parents in terms of the usefulness of technology in children's lives. The openness of parents, manifested in this direction, can be associated with ensuring the well-being of the child, as the literature, research studies and the reality of the XXI century, demonstrate the interest of children in using technology, while reflecting the well-being that children associates technological resources. Following the measurement 
of this frequency, the hypothesis according to which the usefulness of technology for children's development is recognized in the case of parents participating in the study, is confirmed.

Table 4. Parents' opinion about the usefulness of technology for the child's development

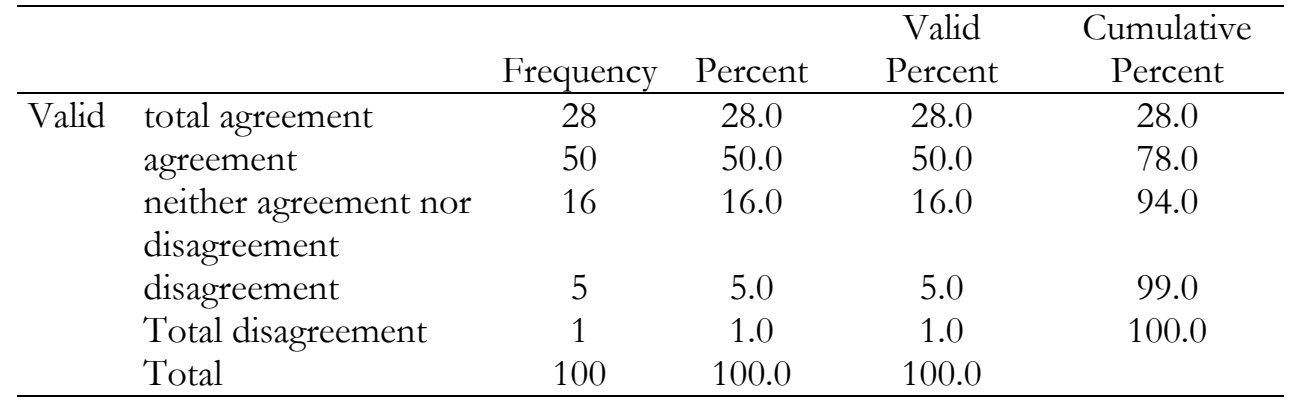

The open mindset of parents regarding the use of technology was demonstrated by measuring the frequency of responses to the statement "My child could teach me how to use technology." Of the 100 respondents, 75 answered in the affirmative. From these statistics, it can be concluded that parents can show flexibility in a parent-child partnership focused on the use of technology. This behaviour is in line with the new paradigm of parenting, according to which the well-being of the child is ensured through an effective parent-child relationship, and the hypothesis that today's parents believe that the parent-child partnership can help ensure the child's wellbeing is confirmed.

Table 5. Parents' opinion on the creation of a parent-child partnership regarding the use of technology

\begin{tabular}{llcccc}
\hline & Frequency & Percent & Valid Percent & $\begin{array}{c}\text { Cumulative } \\
\text { Percent }\end{array}$ \\
\hline Valid & yes & 75 & 75.0 & 75.0 & 75.0 \\
& no & 25 & 25.0 & 25.0 & 100.0 \\
& Total & 100 & 100.0 & 100.0 & \\
\hline
\end{tabular}

Testing the hypothesis that managing the time the child spends using technological resources is a difficulty for parents in today's society, was done by correlating the lack of parental authority with the inability of parents to manage the time children spend in the presence of technology. The coefficient $\mathrm{r}(98)=0,459, \mathrm{p}<0.001$, shows a positive correlation between the two variables, resulting in a strong relationship between the two. 
Following the correlation, we can conclude that those parents who fail to have authority over the child, have difficulty managing the time the child spends in front of technology, so the previously mentioned hypothesis is confirmed. The paradigm of modern parenting encourages ensuring the well-being of the child, but does not diminish the authority that the parent needs to exercise over his child, but dora advocates for its use in a balanced way and adapted to the child's needs.

Table 6. Parents' difficulty in managing the time the child spends using technological resources

\begin{tabular}{|c|c|c|c|}
\hline & & $\begin{array}{l}\text { I have come to } \\
\text { feel that I have } \\
\text { no authority } \\
\text { over my child } \\
\text { since } \\
\text { technology has } \\
\text { taken over his } \\
\text { free time. }\end{array}$ & $\begin{array}{l}\text { Although I am } \\
\text { aware that } \\
\text { there are times } \\
\text { when my child } \\
\text { exaggerates } \\
\text { with the use of } \\
\text { technology, I } \\
\text { do not know } \\
\text { how to stop } \\
\text { this. }\end{array}$ \\
\hline \multirow{2}{*}{$\begin{array}{l}\text { I have come to feel that I have no } \\
\text { authority over my child since } \\
\text { technology has taken over his free } \\
\text { time. }\end{array}$} & $\begin{array}{l}\text { Pearson Correlation } \\
\text { Sig. (2-tailed) }\end{array}$ & 1 & $\begin{array}{c}.459^{* *} \\
.000\end{array}$ \\
\hline & $\mathrm{N}$ & 100 & 100 \\
\hline $\begin{array}{l}\text { Although I am aware that there are } \\
\text { times when my child exaggerates }\end{array}$ & $\begin{array}{l}\text { Pearson Correlation } \\
\text { Sig. (2-tailed) }\end{array}$ & $\begin{array}{l}.459^{* *} \\
.000\end{array}$ & 1 \\
\hline $\begin{array}{l}\text { with the use of technology, I do not } \\
\text { know how to stop this. }\end{array}$ & $\mathrm{N}$ & 100 & 100 \\
\hline
\end{tabular}

Following the correlational analysis between the parent's open vision of technology and its adaptation to technology, the hypothesis was confirmed that: the technological society determines the current parent to adapt to it to ensure the child's well-being.

The Pearson correlation coefficient $r(98)=0,235, p<0,001$ demonstrates the strong relationship between the two correlated variables. We can conclude that those parents who have an open vision on this field, have a more pronounced tendency to adapt to technology, while increasing the probability of ensuring the well-being of the child 
Table 7. The adaptation of the parent to the technological society

*Correlation is significant at the 0.05 level (2-tailed).

\begin{tabular}{|c|c|c|c|}
\hline & & $\begin{array}{l}\text { There are } \\
\text { times when } \\
\text { I choose to } \\
\text { look at the } \\
\text { good side of } \\
\text { technology } \\
\text { and play } \\
\text { with my } \\
\text { child }\end{array}$ & $\begin{array}{l}\text { I think that my life as a } \\
\text { parent would be easier } \\
\text { if I learned to see the } \\
\text { benefits of technology }\end{array}$ \\
\hline There are times when & Pearson & \multirow{2}{*}{ 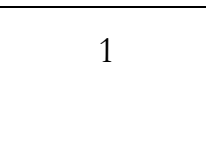 } & \multirow[t]{2}{*}{$.235^{*}$} \\
\hline $\begin{array}{l}1 \text { choose to look at } \\
\text { the good side of }\end{array}$ & $\begin{array}{l}\text { Correlation } \\
\text { Sig. (2-tailed) }\end{array}$ & & \\
\hline $\begin{array}{l}\text { technology and play } \\
\text { with my child }\end{array}$ & $\mathrm{N}$ & 100 & 100 \\
\hline $\begin{array}{l}\text { I think that my life as } \\
\text { a parent would be }\end{array}$ & $\begin{array}{c}\text { Pearson } \\
\text { Correlation }\end{array}$ & $.235^{*}$ & \multirow[t]{2}{*}{1} \\
\hline easier if I learned to & Sig. (2-tailed) & .019 & \\
\hline $\begin{array}{l}\text { see the benefits of } \\
\text { technology }\end{array}$ & $\mathrm{N}$ & 100 & 100 \\
\hline
\end{tabular}

Following the correlation between the age range of the parents and their opinion on the use of technology by the child, in the form of a reward, it is found that respondents in the age range 40 - 45 years, they represent the largest category of the study (32), recorded the most affirmative answers, 4 of them being totally in agreement, while 5 expressed their agreement regarding this statement. By associating the age range with the affirmative answers, we can conclude that with advancing age a rigidity of parents can be registered in terms of the use of technology. Thus, the hypothesis according to which, ensuring the well-being of the child, by the parents, in the form of a reward is associated with the aging of the parents, is confirmed.

The age ranges "40-45" years, respectively "over 50 years", were not taken into account, because there was a small number of respondents in these ranges. According to this association, there is a need for training of 
parents in the field of technology, in the context of adapting to the features of modern society and ensuring the well-being of the child.

Table 8. Ensuring the well-being of the child in the form of a reward

\begin{tabular}{|c|c|c|c|c|c|c|c|}
\hline & & \multicolumn{5}{|c|}{$\begin{array}{l}\text { I believe that the best reward for my child is permission } \\
\text { to use technology }\end{array}$} & \multirow[b]{2}{*}{ Total } \\
\hline & & $\begin{array}{c}\text { total } \\
\text { agreement }\end{array}$ & agreement & $\begin{array}{c}\text { neither } \\
\text { agreement } \\
\text { nor } \\
\text { disagreem } \\
\text { ent } \\
\end{array}$ & $\begin{array}{c}\text { disagreem } \\
\text { ent } \\
\end{array}$ & $\begin{array}{c}\text { total } \\
\text { disagreement } \\
\end{array}$ & \\
\hline \multirow[t]{6}{*}{ age range } & $\begin{array}{l}25-30 \\
\text { years }\end{array}$ & 1 & 0 & 2 & 0 & 3 & 6 \\
\hline & $30-3$ years & 2 & 1 & 10 & 4 & 2 & 19 \\
\hline & $\begin{array}{l}35-40 \\
\text { years }\end{array}$ & 1 & 6 & 6 & 5 & 5 & 23 \\
\hline & $40-4$ yeas & 4 & 5 & 7 & 7 & 9 & 32 \\
\hline & $\begin{array}{l}45-50 \\
\text { years }\end{array}$ & 0 & 2 & 5 & 2 & 3 & 12 \\
\hline & $\begin{array}{l}\text { over } 50 \\
\text { years }\end{array}$ & 1 & 2 & 3 & 1 & 1 & 8 \\
\hline Total & & 9 & 16 & 33 & 19 & 23 & 100 \\
\hline
\end{tabular}

By measuring the frequency with which parents experience an emotional break between themselves and the child, caused by the advancement of technology, it is found that only 6 respondents out of the 100 participants in the study, strongly feel this emotional break, while 75 respondents feel a slight distortion of the parent-child emotional relationship. There are 19 parents who experience this phenomenon moderately, as a result of these statistical results, we can conclude that the parents of the 21st century, manage more easily the effects of technology advancement, on the parent-child relationship, compared to parents in the past. This evolution can be the precursor to the well-being of the child, currently surrounded by the multitude of technological resources. Therefore, the hypothesis that the emotional rupture between parent and child caused 
by the technological society is not felt by parents today, at a high level, is confirmed.

Table 9. Parents' opinion on technology as a factor distorting the parent-child emotional relationship

\begin{tabular}{cccccc}
\hline & & & & Cumulative \\
Valid & Frequency & Percent & Valid Percent & Percent \\
\cline { 2 - 5 } & to a very small extent & 54 & 54.0 & 54.0 & 54.0 \\
& to a small extent & 21 & 21.0 & 21.0 & 75.0 \\
& to a moderate extent & 19 & 19.0 & 19.0 & 94.0 \\
& to a large extent & 5 & 5.0 & 5.0 & 99.0 \\
to a very large extent & 1 & 1.0 & 1.0 & 100.0 \\
& 100 & 100.0 & 100.0 & \\
\hline
\end{tabular}

\section{Discussions}

The present research provides an overview of the importance of the child's well-being, a well-being that begins to develop in the family environment, and then to be transferred to the digital society. This society, a modern society, is characterized by diversity, consumerism, individualism, but also rapid social change.

An essential change in today's society is the redefinition of the parenting paradigm, which encourages the development of parental competence among parents today, adapting parents to the needs of the child, using emotional intelligence in the parent-child relationship, offering unconditional love and creating a parent-child partnership, including in the use of technology.

The digital society provides the necessary tools to ensure the wellbeing of children, but on the other hand, challenges parents to find sufficient strategies to balance the well-being acquired through the use of various technological resources with the well-being obtained through activities which does not involve technology. A good strategy for creating this balance is to create a parent-child partnership.

A strong point of this research is represented by the fact that it considers the study of a topical issue, namely the perception of parents on 
the well-being of their children as a result of redefining the paradigm of parenting.

Another strong point of the paper is the testing of hypotheses with a large sample, representing a total of 119 parents.

The limit of the study is represented by the equal results obtained after calculating the frequency of parents who want to document themselves regarding the parenting strategies specific to the technological society, respectively the parents who refuse this. In order to determine exactly what the conclusion is regarding these results; it is necessary to apply the questionnaire to a larger sample.

From a practical point of view, this study demonstrates the usefulness of developing parental competence, especially from the point of view of the management by the parent of the time that the child spends in the presence of technological resources. The development of this competence among the parents of today's society will provide the parent with all the tools he needs to ensure the well-being of his child, which, as we mentioned in the initial phase of the study, starts at home.

The main conclusion of the research is that the well-being of children is dependent on the adaptation of parents to the technological society, a society that requires the parent to face a series of challenges in raising and educating his child, but provides the necessary tools for the creation of the parent-child partnership and implicitly for the efficient relationship.

\section{Conclussions}

Through this research, eight hypotheses were tested, and all the hypotheses established in the initial phase were validated. Thus, following the research, the following aspects were demonstrated, respectively concluded:

The parents participating in the study demonstrated that they are involved in ensuring the well-being of their child, using different strategies in this regard, being also interested in studying modern parenting. It is also worth noting the parents' awareness of the role that technology has on the 
child's development, as well as the acceptance of the idea that the parentchild partnership can help ensure the well-being of the latter.

The management by the parent of the time that the child spends in the presence of digital resources, is a difficulty for the parents of today's society, this demonstrating a growing need for the development of parental competence.

It is found that the assurance by the parent of the child's well-being also implies an adaptation to the technological society, as well as the renunciation of the association of this state with a reward.

It should be noted that although the technology is evolving rapidly, for the parents participating in this study, it was not a cause of deterioration of the parent-child relationship, from an emotional point of view.

\section{References}

Bers, M. U., New, R. S, \& Boudreau, L. (2004). Teaching and Learning when No One Is Expert: Children and Parents Explore Technology. Early Childhood Research \& Practice, 6(2), n2.

https://files.eric.ed.gov/fulltext/EJ1084881.pdf

Cozolino, L. (2017). Predarea bazată pe atasament. Cum creezৃi o clasă tribală

[Attachment-Based Teaching. Creating a Tribal Classroom] (C. Dumitru, Trans.). Trei Publishing House. Original work published 2014 )

Gold, J. (2016). Părinte în era digitală. Învață-ţi copilul cum să folosească adecvat rețelele sociale şi aparatele digitale (Parent in digital age. Learn your child how to use social networking and digital devices] (A. Sevcenco, Trans.). Trei Publishing House. (Original work published 2014)

Gordon, T. (2003). Teacher effectiveness training. Three Rivers Press.

Gordon, T. (2014). Parrintele eficient [Parent Effectiveness Training. The Proven Program For Raising Responsible Children] (V. Popescu, Trans.). Trei Publishing House. (Originak work published 2000).

Hofstede, G. (1980). Culture's Consequences: International Differences in Work-Related Values. Sage.

Hofstede, G. (1991). Cultures and Organizations. Software of the Mind, McGraw-Hill 
Kohn, A. (2015). Parenting necondiționat. De la recompense si pedepse la iubire si intelegere [Unconditional Parenting: Moving from Rewards and Punishments to Love and Reason] (M. Losonti, Trans.). Multi Media Est Publishing. (Originak work published 2005).

Kohn, A. (2017). Mitul copilului răsfătat [The Myth of the Spoiled Child: Challenging the Conventional Wisdom about Children and Parenting] (S. Watt, Trans.). Editura Herald. (Original work published 2014)

Palladino, L. J. (2015). Copiii în epoca dependenței de tehnologie. Noile dispozitive digitale şi riscurile utilizării lor excesive [Children in the age of technology addiction. New digital devices and the risks of their excessive use] (M. Andriescu, Trans.). Polirom Publishing House.

Patton, M.Q (2002). Qualitative Research \& evaluation Methods (3 ${ }^{\text {rd }}$ ed.). Sage Publication.

Realo, A., Koido, K., Ceulemans, E., \& Allik, J. (2002). Three Components of Individualism. European Journal of Personality, 16(3), 163-184. https://doi.org/10.1002/per.437

Veen, W., \& Vrakking, B. (2011). Homo Zappiens. Joc şi învătare în epoca digitală [Homo Zappiens. Play and learning in the digital age]. Sigma Publishing House. (Original work published 2007)

Voicu, B., Rusu, H. M., \& Popa, A. E. (2016). Sociologie, societate şi schimbare socială [Sociology, society and social change]. "Lucian Blaga” University Publishig House. 